Academic City University College - Accra Ghana

Society for Multidisciplinary \& Advanced Research Techniques (SMART) Africa

Tony Blair Institute for Global Change

FAIR Forward - Artificial Intelligence for All - Deutsche Gesellschaft für Internationale Zusammenarbeit (GIZ) GmbH

Accra Bespoke Multidisciplinary Innovations Conference (ABMIC)

\& The Africa Al Stakeholders' Summit

$14^{\text {th }}$ December, 2021

\title{
Impacts of Anthropogenic Activities on the Fish Compositions and Diversity of Okerenkoko Estuarine, Delta State, Nigeria
}

\author{
Ewutanure, S.J. \& Binyotubo, T.E. \\ Department of Fisheries and Aquaculture, \\ Faculty of Marine Environmental Management, \\ Nigeria Maritime University, \\ Okerenkoko, Warri - South, Delta State, Nigeria. \\ E-mail: ewutanure@gmail.com \\ Phone: +2348101634482 .
}

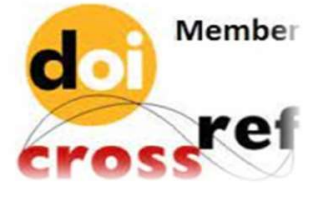

Proceedings Citation Format

Ewutanure, S.J. \& Binyotubo, T.E. (2021): Impacts of Anthropogenic Activities on the Fish Compositions and Diversity of Okerenkoko Estuarine, Delta State, Nigeria. Proceedings of the Accra Bespoke Multidisciplinary Innovations Conference. University of Ghana/Academic City University College, Accra, Ghana. December 2021. Pp 9-22 www.isteams.net/ghanabespoke2021. DOI https://doi.org/ 10.22624/AIMS/ABMIC2021-V2-P2x 


\title{
Impacts of Anthropogenic Activities on the Fish Compositions and Diversity of Okerenkoko Estuarine, Delta State, Nigeria
}

\author{
Ewutanure, S.J. \& Binyotubo, T.E..
}

\begin{abstract}
Water quality impairment due to anthropogenic activities affects fishery resources. Surface water bodies in the Niger Delta Region of Nigeria are being adversely impacted by the effects of pollution and the destruction of its fishery resources. This study was carried out to assess the impacts of anthropogenic activities on the fish compositions and diversity of Okerenkoko Estuarine, Delta State, Nigeria. Okerenkoko Estuarine $(62.79 \mathrm{Km})$ was spatially stratified into five stations (Z1, Z2, Z3, Z4 and Z5) based on nearness to major anthropogenic activities. Temporal stratification covered June to December. Fish samples were collected for 7 months from each station at the study area with prior arrangement with the fishers. Fishing gears used were Mid - Water Drift Gill Net of mesh sizes $101 \mathrm{~mm}$ and $127 \mathrm{~mm}$; Bottom Set Gill Net (50 $100 \mathrm{~m}$ ) of mesh size $76 \mathrm{~mm}, 101 \mathrm{~mm}$ and $127 \mathrm{~mm}$; Hook and line (2-6 m) of hook sizes No. 5, No. 7, No. 8, No. 9, No. 12 and No. 15; Long Line (300 - 1000 m) of hook sizes No. 7, No. 8. Parameters determined were Numbers of Species, Abundance (\%), Simpson and Shannon by using standard procedures. Data were analysed by using Excel (Window 10) and Palaeontological Statistics (Past Version 3.6). A total number of 1261 of fishes and 45 species belonging to 14 families were identified. Highest 383 (30.4\%) and least 152 (12.1\%) number of fishes were obtained in Z5 and Z4, respectively. The most abundant fish species recorded was Sardinella aurita 192 (15.2\%), while the least was Sphyraena afra 1 (0.1\%), respectively. Temporally, the highest 331 (26.2 \%) and least 45 (3.6 \%) fish species Occurred in December and September. Simpson index ranged from 0.69 to 0.89 in Z1 and Z3, Shannon $(1.97,2.98)$ occurred in Z4 and Z2, respectively. Fish biodiversity richness (0.69) of Okerenkoko Estuarine could be threatened.
\end{abstract}

Keywords: Water quality, Anthropogenic activities, Fishing gears, Niger Delta and Pollution.

\section{INTRODUCTION}

The coastal environment

The coastal ecosystem is known as the interface between three habitable environments which are: the earth, air and sea (Egorge 2010). All coastal area contains at least two major habitats which are the (i) marine time zone and (ii) sea itself (Egborge 2001; Olaifa, 2003; Ogaga et al. 2015a). Ohimain et al., (2008a) reported that a combination of the increasing pollution, agricultural modernisation and human population largely hampered the productivity of coastal waters. Industrial effluent is one of the main sources of aquatic pollution in Nigeria Ohimain et al., (2008b). Discharged of industrial effluents directly into the aquatic environment without treatment have the capacity of increasing water quality parameters abnormally Ohimain, (2002); Ogaga et al., (2015a). This has led to excessive load of inorganic metals ( $\mathrm{Pb}, \mathrm{Cr}$ and $\mathrm{Fe}$ ) in most water bodies (Nodu and Ohimain, 2014). The resultant impacts on the receiving water bodies include be reduction in the abundance and diversity of flora and fauna species and water quality impairment (Ohimain, 2008). 
High phosphate levels in these effluents may lead to a rise in nutrients in the receiving water bodies thereby leading to ecological disaster (Ewutanure and Olaifa, 2018a). The Marine, Estuarine and Freshwater ecosystem of Nigeria is endowed with abundant fisheries resources (Ita, 1993). Nigeria has eight coastal states which include: Ogun; Lagos; Ondo; Delta; Bayelsa; Akwa-Ibom and Cross River States (Ewutanure and Olaifa, 2017). The activities of the oil companies within the Niger - Delta Region of Nigeria have drastically reduced its surface water quality (Olaifa et al. 2019). This has led to water scarcity and poor aesthetic value.

Most of the Estuaries and rivers within the Niger - Delta Region of the country cannot be treated for both aquaculture and drinking purposes because of the impact of oil pollution (Ewutanure and Olaifa, 2018b). The decline in fisheries resources of Nigeria could be linked with over exploitation and inadequate management of her coastal waters (Ogbeibu and Ezeunara, 2002). For sustainability of these resources, an adequate knowledge of species compositions and abundance of her water bodies must be recognised and be deliberately pursued.

The establishment of industries and urban development along the shores of surface water may injected large volume of organic and inorganic wastes into its water (Ewutanure and Olaifa, 2021). Increase urbanisation and industrialization, non - standard town planning system and inadequate regulation and enforcement activities could serve as means for the release of untreated effluents into the aquatic environment and its adjoining tributaries. The people of Okerenkok Communities rely on the Estuarine for fishing activities and as a major source of transportation.

But oil exploitation, dredging, reclamation, sand mining and waste water disposal are the main anthropogenic activities carried out in the Niger Delta Region (Aghoghovwia et al. 2015b). The main anthropogenic activities in most coastal communities of the Niger Delta Region is oil exploration which include seismic exploration, drilling and completion, construction, installation and operation of production facilities such as flow stations, compressor stations, gas plants and pipelines (Aghoghovwia, 2008).

Effluents from the production facilities are being constantly discharged into Okerenkok Estuarine, while gas flaring has continued uncontrollably. Solid wastes from artisanal refineries equally release effluents into the estuarine. In Okerenkok Estuarine, oil spillage is a common phenomenon, while Ogaga et al., (2015b) was of the opinion that this could result in the death of flora and fauna abundance in a water body. Ewutanure and Olaifa, (2017) reported that the presence of oil and gas infrastructure, oil spills are now increasing in the Niger Delta due to illegal oil bunkering and artisanal refineries.

\section{Fisheries resources of Delta State}

Olaifa, (2004) reported some fisheries resources of Delta State to include four main types which include: The coastal pelagic fishery with some of its catches as Ethmalosa fimbriata (bonga), Ilisha africana (shad), Sardinella eba; Freshwater fishery with some of its compositions as Clarias gariepinus, Oreochromis niloticus, Xenomystus nigri, Hemisynodontis membranaceous, Malapterurus electricus, Siluranodon auritus and Hepsetus odoe; Coastal demersal fishery with some of the catches as Pseudolithus typpus and P. brachygnathus (croakers), Chrysichthys nigrodigitatus, Arius sp.; Cyanoglossus goreensis (sole), Luthjanus sp. (snappers); Polydactylus quadrifilis (shiny nose) and the Cray fish fishery. The presence of a standing crop of penaeids shrimps off coast of Delta State has been reported (Idodo - Umeh, 2004). 
Artisanal fishers harvest large size penaeids and Palaemonids shrimps but the largest crustaceans caught are the tiny Carideid shrimps (Palaemonidae) and the juveniles of Penaeus notialis that breeds in the sediment rich estuarine and brackish mangrove swamps (Ogaga et al. 2015b). The species are usually smoked dried and commonly referred to as crayfish in Nigeria.

Reasons for decline in fish yield

An estimated $40 \%$ of the total protein in - take of Nigerians is obtained from fish (Olaifa, 2015). It has been reported that surface water bodies are the most endangered ecosystem (Ewutanure and Olaifa, 2017). In most parts of the world, inland water ecosystems are over fished and are mostly degraded by the devastating effects of pollution (Baran and Guerin, 2014). With respect to population explosion and rise in technology, decrease in the abundance and fish diversity are fast becoming a major concern.

Habitat alteration and loss, climatic changes, surface water pollution, invasive species and over exploitation of the fishery resources are some of the factors responsible for the decline in fish species abundance in the inland water bodies of Nigeria (Olaifa, 2006). The coastal areas are subject to the negative effects of anthropogenic activities. Industrial waste may contain heavy metals such as copper, zinc, lead, cadmium, nickel, chromium and iron which may be toxic to fish and eventually bio - accumulate in man through the food chain.

Aghoghovwia et al., (2015a) linked the decline in fisheries resources of the Niger Delta to oil and gas exploration in the area. A comparison of the fish fauna of Okerenkok Estuarine and some inland river such as Warri River, Ase, Ogun and Niger/Benue show that these water bodies have wide variety of fish species diversity. Fish fauna of Nigerian freshwater bodies has been the major focus of research for quite sometimes (Ogaga et al. 2015), while the paucity of information on the fisheries resources of Okerenkoko Estuarine, birthed this research into the determination of its fish species compositions and diversity.

\section{MATERIALS AND METHODS}

Description of the Study Area

Okerenkok Estuarine is located within latitudes $5^{\circ} 30^{\prime} 0^{\prime \prime} \mathrm{N}$ and $5^{\circ} 50^{\prime} 0^{\prime \prime} \mathrm{N}$ of the Equator and Longitudes $5^{\circ} 10^{\prime} 0^{\prime \prime} \mathrm{E}$ and $5^{\circ} 40^{\prime} 0^{\prime \prime} \mathrm{E}$ of the Greenwich meridian (Figure 1). Its source is the Eschravos River. It situated in Warri - South Local Government Area of Delta State, Nigeria. Okerenkoko Estuarine with an average depth of $35 \mathrm{~m}$ is $62.79 \mathrm{Km}$ long. Okerenkoko Estuarine was spatially stratified into five stations (Z1, Z2, Z3, Z4 and Z5) based on closeness to major anthropogenic activities. Temporal stratification covered June to December. Fish samples were collected for 7 months from each station at the study area with prior arrangement with the fishers. Collected fish samples were identified to species level, counted and recorded by using standard keys (Boulenger, 1909 - 1916; Hoden and Reed, 1972; Idodo - Umeh, 2003). Fish were caught using Mid - Water Drift Gill Net of mesh sizes $101 \mathrm{~mm}$ and $127 \mathrm{~mm}$; Bottom Set Gill Net (50 - $100 \mathrm{~m}$ ) of mesh size $76 \mathrm{~mm}, 101 \mathrm{~mm}$ and $127 \mathrm{~mm}$; Ita Trap (7 - $15 \mathrm{~m}$ ) of mesh sizes $12.5 \mathrm{~mm}, 24 \mathrm{~mm}, 25 \mathrm{~mm}, 76 \mathrm{~mm}, 127 \mathrm{~mm}$ and $144 \mathrm{~mm}$; Ngo Trap (5 m) of mesh size $12 \mathrm{~mm}$; Stone Trap (5.7 m) of mesh sizes $12 \mathrm{~mm}, 24 \mathrm{~mm}, 48 \mathrm{~mm}$; Gura Fishing Trap (1 m) of mesh sizes $12 \mathrm{~mm}, 24 \mathrm{~mm}, 48 \mathrm{~mm}$; Shore net gill net (30 - $100 \mathrm{~m})$ of mesh sizes $24 \mathrm{~mm}$ and $62 \mathrm{~mm}$; Tilapia Cast net of mesh sizes $76 \mathrm{~mm}, 101 \mathrm{~mm}$ and $127 \mathrm{~mm}$; Surface Bonga Drift Net $(100-500 \mathrm{~m})$ of mesh sizes $40 \mathrm{~mm}, 52 \mathrm{~mm}$ and $64 \mathrm{~mm}$; Bottom Drift Gill Net (50 - $100 \mathrm{~m})$ of 
mesh sizes $64 \mathrm{~mm}, 76 \mathrm{~mm}$ and $125 \mathrm{~mm}$; Beach Seine net (50 - $200 \mathrm{~mm}$ ) of mesh sizes 25 $\mathrm{mm}, 38 \mathrm{~mm}, 50 \mathrm{~mm}$, ply 18 and 3b; Cast Net (3- $7 \mathrm{~m}$ ) of mesh sizes $38 \mathrm{~mm}, 50 \mathrm{~mm}, 62 \mathrm{~mm}$ and $76 \mathrm{~mm}$; Hook and line $(2-6 \mathrm{~m})$ of hook sizes No. 5, No. 7, No. 8, No. 9, No. 12 and No. 15; Long Line (300 - 1000 m) of hook sizes No. 7, No. 8, No. 9, No. 12 and No. 15, respectively.

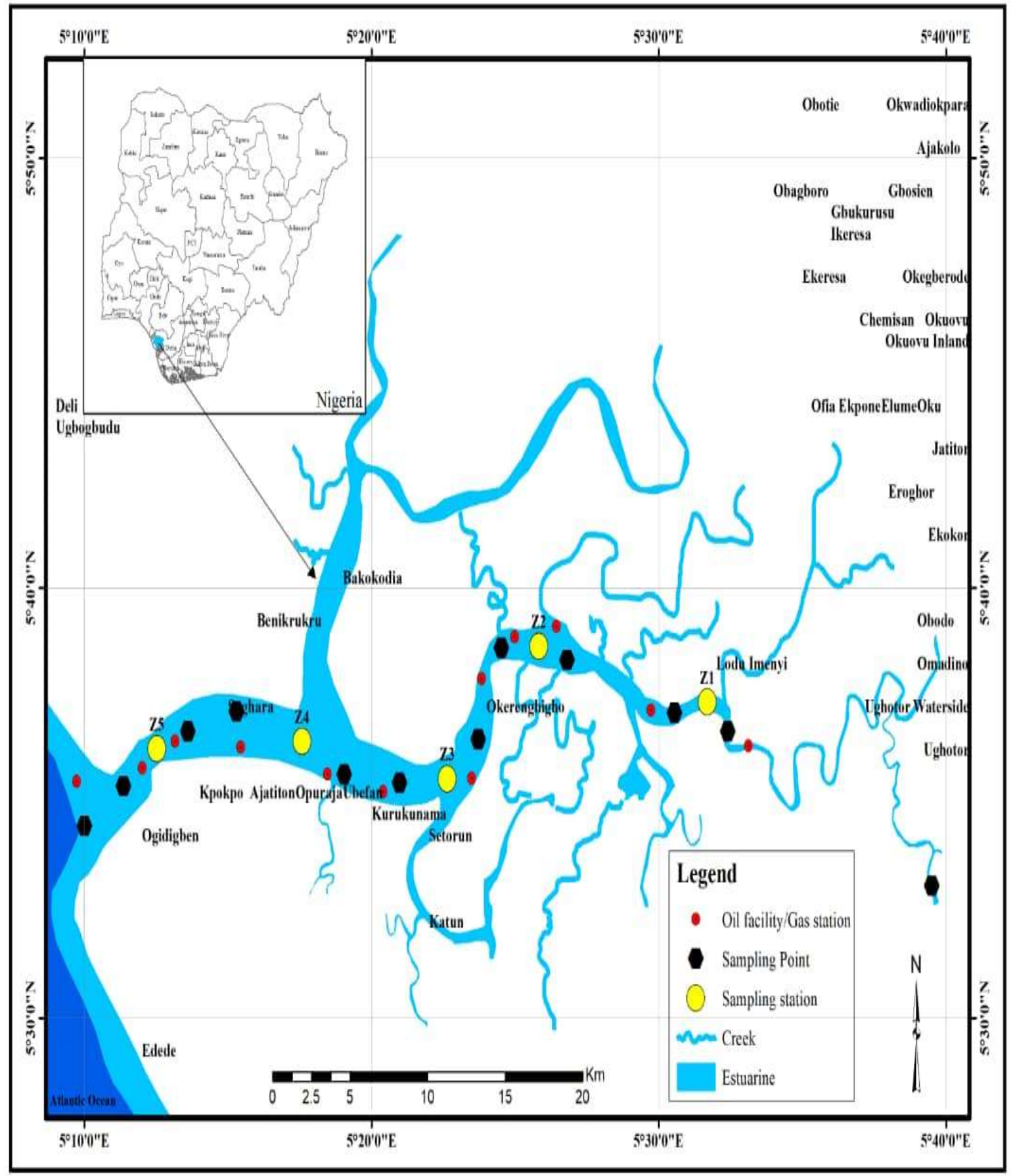

Figure 1. Map of Okerenkoko Estuarine Source: Ewutanure, (2021) 


\section{Diversity index calculated}

Margalef's Diversity Index

$R i=\frac{S-1}{\ln (N)}$

Margalef, (1958)

$\mathrm{S}=$ Total number of species, $\mathrm{N}=$ Total density of species.

Simpson's index $\left(\mathrm{S}_{\mathrm{i}}\right)=1$ - Dominance. It is a measurement of evenness

$\mathrm{Si}=\frac{D}{D \max }$

Llody, 1964

$S_{i}$ measures the evenness/richness of the community from $0-1$,

$\mathrm{D}=$ Species diversity, Dmax = Maximum amount of the species' diversity index

Shannon-Wiener Index

$H^{\prime}=-\sum_{i=1}^{n} P i \log 2 P i \quad$ Shannon and Weaver, 1949

It takes into account the number of individuals as well as the number of taxa. It varies from 0 (community with only a single taxa) to high values (community with many taxa) each with few individual. $\mathrm{n}=$ Total number of species $\mathrm{I}, \mathrm{P}_{\mathrm{i}}=$ Ratio of the species $\mathrm{i}$.

\section{Statistics}

The data were analysed using Excel (Window 10 and Palaeontological Statistics (Past, version 3.6).

\section{RESULTS}

The results of fish species abundance and distribution among Stations and Months are presented in Tables 1 and 2, while Species diversity index are shown in Table 3, respectively. A total of 1261 number of fishes comprising 14 families and forty - five (45) fish species were identified during the study. Stations Z5 recorded the highest 383 (30.4\%) followed by Z3 264 (20.9\%), while Z1 and Z2 recorded same 231 (18.3\%) number of fishes, respectively. Spatially, the most abundant fish species recorded was Sardinella aurita 192 (15.2\%) followed by Ethmalosa fimbriata 62 (4.9\%), while the least was Sphyraena afra 1 (0.1\%), respectively.

Sardinella aurita 260 (20.6\%) and Sphyraena afra 2 (0.2 \%) were recorded as the highest and least fish species in December and October, respectively. The highest number of fishes were recorded in December 331 (26.2 \%) followed by November 244 (19.3\%), August 233 (18.5\%), July 229 (18.2\%), while the least occurred in September 45 (3.6\%), respectively. Simpson index ranged from 0.69 to 0,89 in Z1 and Z3, Shannon $(1.97,2.98)$ occurred in Z4 and Z2, Evenness $(0.31,0.85)$ were obtained in Z3 and Z1, Margalef $(1.41,2.91)$ were obtained in Z1 and Z3, respectively. 
Table 1. Abundance and distribution of fish species in Okerenkoko Estuarine among Stations

\begin{tabular}{|c|c|c|c|c|c|c|c|c|}
\hline \multirow{2}{*}{ Families } & \multirow[b]{2}{*}{ Species } & \multicolumn{5}{|c|}{ Stations } & \multirow[b]{2}{*}{ Total } & \multirow[b]{2}{*}{ Percentage } \\
\hline & & Z1 & $\mathrm{Z2}$ & Z3 & Z4 & Z5 & & \\
\hline \multirow[t]{5}{*}{ Sparidae } & $\begin{array}{l}\text { Diplodus } \\
\text { carvinus }\end{array}$ & 3 & 6 & 9 & 4 & 3 & 25 & 2.0 \\
\hline & D. puntazzo & 3 & 9 & 5 & 9 & 7 & 33 & 2.6 \\
\hline & D. sarqus & 1 & 6 & 3 & 1 & 3 & 14 & 1.1 \\
\hline & $\begin{array}{l}\text { Pagellus } \\
\text { bagaravo }\end{array}$ & 3 & 4 & 3 & 3 & 0 & 13 & 1.0 \\
\hline & Pagrus pagrus & 11 & 7 & 4 & 6 & 7 & 35 & 2.8 \\
\hline \multirow[t]{3}{*}{ Sciaenidae } & $\begin{array}{l}\text { Pseudotolithus } \\
\text { enlonagutus }\end{array}$ & 9 & 7 & 6 & 2 & 3 & 27 & 2.1 \\
\hline & P. typus & 9 & 7 & 3 & 1 & & 20 & 1.6 \\
\hline & $\begin{array}{l}P . \\
\text { senegalensis }\end{array}$ & 1 & 1 & 3 & 5 & 0 & 10 & 0.8 \\
\hline \multirow[t]{3}{*}{ Polynemidae } & $\begin{array}{l}\text { Galeoides } \\
\text { decadactylus }\end{array}$ & 9 & 6 & 12 & 1 & 0 & 28 & 2.2 \\
\hline & $\begin{array}{l}\text { Pentanemus } \\
\text { quinquarius }\end{array}$ & 5 & 6 & 7 & 2 & 1 & 21 & 1.7 \\
\hline & $\begin{array}{l}\text { Polydactylus } \\
\text { quadritilis }\end{array}$ & 2 & 7 & 10 & 4 & 1 & 24 & 1.9 \\
\hline \multirow[t]{3}{*}{ Scombridae } & $\begin{array}{l}\text { Scomberus } \\
\text { totor }\end{array}$ & 4 & 3 & 4 & 7 & 3 & 21 & 1.7 \\
\hline & $\begin{array}{l}\text { Euthynnus } \\
\text { alleteratus }\end{array}$ & 7 & 2 & 5 & 1 & 0 & 15 & 1.2 \\
\hline & $\begin{array}{l}\text { Katsuwonus } \\
\text { palamis }\end{array}$ & 7 & 5 & 3 & 1 & 1 & 17 & 1.3 \\
\hline \multirow[t]{3}{*}{ Lutjanidae } & $\begin{array}{l}\text { Lutjanus } \\
\text { agennes }\end{array}$ & 7 & 5 & 6 & 2 & 0 & 20 & 1.6 \\
\hline & L. dentatus & 4 & 1 & 2 & 6 & 7 & 20 & 1.6 \\
\hline & $\begin{array}{l}\text { L. } \\
\text { endecacanthus }\end{array}$ & 1 & 0 & 7 & 4 & 10 & 22 & 1.7 \\
\hline \multirow[t]{3}{*}{ Ariidae } & Arius gigas & 10 & 19 & 16 & 0 & 5 & 50 & 4.0 \\
\hline & A. heudeiot & 1 & 5 & 6 & 7 & 3 & 22 & 1.7 \\
\hline & A. laticutatus & 4 & 9 & 11 & 8 & 5 & 37 & 2.9 \\
\hline \multirow[t]{4}{*}{ Cynoglossidae } & $\begin{array}{l}\text { Cynoglossus } \\
\text { brown }\end{array}$ & 3 & 12 & 15 & 11 & 7 & 48 & 3.8 \\
\hline & C. cadenati & 1 & 9 & 4 & 1 & 3 & 18 & 1.4 \\
\hline & $\begin{array}{l}\text { C. } \\
\text { senegalensis }\end{array}$ & 3 & 8 & 3 & 3 & 0 & 17 & 1.3 \\
\hline & $\begin{array}{l}\text { Symphurus } \\
\text { normani }\end{array}$ & 11 & 7 & 4 & 6 & 7 & 35 & 2.8 \\
\hline
\end{tabular}


Table 1. Abundance and distribution of fish species in Okerenkoko Estuarine among Stations Cont'd

\begin{tabular}{|c|c|c|c|c|c|c|c|c|}
\hline \multirow[b]{2}{*}{ Families } & \multirow[b]{2}{*}{ Species } & \multicolumn{5}{|c|}{ Stations } & \multirow[b]{2}{*}{ Total } & \multirow{2}{*}{$\begin{array}{l}\text { Percentag } \\
\text { e (\%) }\end{array}$} \\
\hline & & Z1 & Z2 & Z3 & Z4 & Z5 & & \\
\hline \multirow[t]{3}{*}{ Soleidae } & $\begin{array}{l}\text { Monochirus } \\
\text { hispidus }\end{array}$ & 6 & 9 & 1 & 2 & 0 & 18 & 1.4 \\
\hline & $\begin{array}{l}\text { Pequsa } \\
\text { cadenati }\end{array}$ & 12 & 10 & 1 & 1 & 2 & 26 & 2.1 \\
\hline & P. lascoris & 13 & 9 & 5 & 6 & 3 & 36 & 2.9 \\
\hline \multirow[t]{4}{*}{ Mugiledae } & $\begin{array}{l}\text { Mugil } \\
\text { bananasis }\end{array}$ & 0 & 1 & 5 & 3 & 10 & 19 & 1.5 \\
\hline & M. cephalus & 20 & 1 & 2 & 3 & 20 & 46 & 3.6 \\
\hline & M. curema & 3 & 1 & 4 & 5 & 1 & 14 & 1.1 \\
\hline & $\begin{array}{l}\text { Liza } \\
\text { dumerilli }\end{array}$ & 2 & 3 & 6 & 0 & 9 & 20 & 1.6 \\
\hline \multirow[t]{4}{*}{ Clupeidae } & $\begin{array}{l}\text { Ilisha } \\
\text { Africana }\end{array}$ & 1 & 1 & 1 & 3 & 2 & 8 & 0.6 \\
\hline & $\begin{array}{l}\text { Pollonula } \\
\text { leonensis }\end{array}$ & 9 & 4 & 5 & 2 & 11 & 31 & 2.5 \\
\hline & $\begin{array}{l}\text { Ethmalosa } \\
\text { fimbriata }\end{array}$ & 4 & 6 & 3 & 6 & 43 & 62 & 4.9 \\
\hline & $\begin{array}{l}\text { Sardinella } \\
\text { aurita }\end{array}$ & 1 & 15 & 19 & 7 & 150 & 192 & 15.2 \\
\hline \multirow[t]{3}{*}{ Carangidae } & $\begin{array}{l}\text { Caranx } \\
\text { crysos }\end{array}$ & 23 & 5 & 50 & 9 & 8 & 95 & 7.5 \\
\hline & C. hippos & 8 & 2 & 7 & 2 & 35 & 54 & 4.3 \\
\hline & C. latus & 9 & 10 & 1 & 6 & 11 & 37 & 2.9 \\
\hline \multirow[t]{3}{*}{$\begin{array}{l}\text { Sphyrangida } \\
\text { e }\end{array}$} & $\begin{array}{l}\text { Sphyraena } \\
\text { afra }\end{array}$ & 0 & 0 & 0 & 1 & 0 & 1 & 0.1 \\
\hline & S. barracuda & 0 & 3 & 1 & 0 & 2 & 6 & 0.5 \\
\hline & $\begin{array}{l}\text { S. } \\
\text { quachancho }\end{array}$ & 1 & 0 & 2 & 1 & 0 & 4 & 0.3 \\
\hline \multicolumn{2}{|c|}{ Total } & 231 & 231 & 264 & 152 & 383 & & \\
\hline \multicolumn{2}{|c|}{ Percentage } & 18.3 & 18.3 & 20.9 & 12.1 & 30.4 & & \\
\hline
\end{tabular}


Table 2. Monthly abundance and distribution of fish species in Okerenkoko Estuarine

\begin{tabular}{|c|c|c|c|c|c|c|c|c|c|c|}
\hline \multirow[b]{2}{*}{ Families } & \multirow[b]{2}{*}{$\begin{array}{l}\text { Genus \& } \\
\text { Species }\end{array}$} & \multicolumn{7}{|c|}{ Catch per month } & \multirow[b]{2}{*}{ Total } & \multirow[b]{2}{*}{$\%$} \\
\hline & & Jun & Jul & Sep. & Aug & Oct. & Nov. & Dec. & & \\
\hline \multirow[t]{5}{*}{ Sparidae } & $\begin{array}{l}\text { Diplodus } \\
\text { carvinus }\end{array}$ & 5 & 12 & 14 & 7 & 4 & 0 & 0 & 42 & 3.3 \\
\hline & D. puntazzo & 4 & 13 & 14 & 10 & 7 & 0 & 0 & 48 & 3.8 \\
\hline & D. sarqus & 2 & 10 & 3 & 1 & 2 & 0 & 0 & 18 & 1.4 \\
\hline & $\begin{array}{l}\text { Pagellus } \\
\text { bagaravo }\end{array}$ & 3 & 9 & 3 & 1 & 0 & 0 & 0 & 16 & 1.3 \\
\hline & Pagrus pagrus & 12 & 10 & 4 & 3 & 1 & 0 & 0 & 30 & 2.4 \\
\hline \multirow[t]{3}{*}{ Sciaenidae } & $\begin{array}{l}\text { Pseudotolithus } \\
\text { enlonagutus }\end{array}$ & 10 & 15 & 5 & 1 & 2 & 0 & 0 & 33 & 2.6 \\
\hline & P. typus & 7 & 8 & 4 & 1 & 0 & 0 & 0 & 20 & 1.6 \\
\hline & $\begin{array}{l}P . \\
\text { senegalensis }\end{array}$ & 2 & 2 & 4 & 2 & 1 & 0 & 0 & 11 & 0.9 \\
\hline \multirow[t]{3}{*}{ Polynemidae } & $\begin{array}{l}\text { Galeoides } \\
\text { decadactylus }\end{array}$ & 9 & 10 & 12 & 1 & 0 & 0 & 0 & 32 & 2.5 \\
\hline & $\begin{array}{l}\text { Pentanemus } \\
\text { quinquarius }\end{array}$ & 5 & 7 & 8 & 1 & 2 & 0 & 0 & 23 & 1.8 \\
\hline & $\begin{array}{l}\text { Polydactylus } \\
\text { quadritilis }\end{array}$ & 3 & 14 & 12 & 2 & 0 & 0 & 0 & 31 & 2.5 \\
\hline \multirow[t]{3}{*}{ Scombridae } & $\begin{array}{l}\text { Scomberus } \\
\text { totor }\end{array}$ & 5 & 4 & 5 & 3 & 0 & 0 & 0 & 17 & 1.3 \\
\hline & $\begin{array}{l}\text { Euthynnus } \\
\text { alleteratus }\end{array}$ & 6 & 4 & 7 & 0 & 2 & 0 & 0 & 19 & 1.5 \\
\hline & $\begin{array}{l}\text { Katsuwonus } \\
\text { palamis }\end{array}$ & 4 & 2 & 4 & 2 & 0 & 1 & 2 & 15 & 1.2 \\
\hline \multirow[t]{3}{*}{ Lutjanidae } & $\begin{array}{l}\text { Lutjanus } \\
\text { agennes }\end{array}$ & 5 & 4 & 7 & 3 & 1 & 0 & 1 & 21 & 1.7 \\
\hline & L. dentatus & 6 & 0 & 0 & 5 & 4 & 1 & 3 & 19 & 1.5 \\
\hline & $\begin{array}{l}\text { L. } \\
\text { endecacanthus }\end{array}$ & 0 & 2 & 9 & 6 & 9 & 0 & 0 & 26 & 2.1 \\
\hline \multirow[t]{3}{*}{ Ariidae } & Arius gigas & 9 & 21 & 11 & 4 & 1 & 0 & 0 & 46 & 3.6 \\
\hline & A. heudeiot & 0 & 1 & 12 & 1 & 2 & 0 & 0 & 16 & 1.3 \\
\hline & A. laticutatus & 0 & 10 & 13 & 0 & 1 & 0 & 0 & 24 & 1.9 \\
\hline \multirow[t]{4}{*}{ Cynoglossidae } & $\begin{array}{l}\text { Cynoglossus } \\
\text { brown }\end{array}$ & 0 & 10 & 12 & 0 & 1 & 0 & 0 & 23 & 1.8 \\
\hline & C. cadenati & 1 & 12 & 13 & 0 & 2 & 0 & 0 & 28 & 2.2 \\
\hline & $\begin{array}{l}\text { C. } \\
\text { senegalensis }\end{array}$ & 0 & 10 & 13 & 0 & 0 & 0 & 0 & 23 & 1.8 \\
\hline & $\begin{array}{l}\text { Symphurus } \\
\text { normani }\end{array}$ & 1 & 11 & 10 & 1 & 0 & 0 & 0 & 23 & 1.8 \\
\hline
\end{tabular}


Table 2. Monthly abundance and distribution of fish species in Okerenkoko Estuarine cont'd

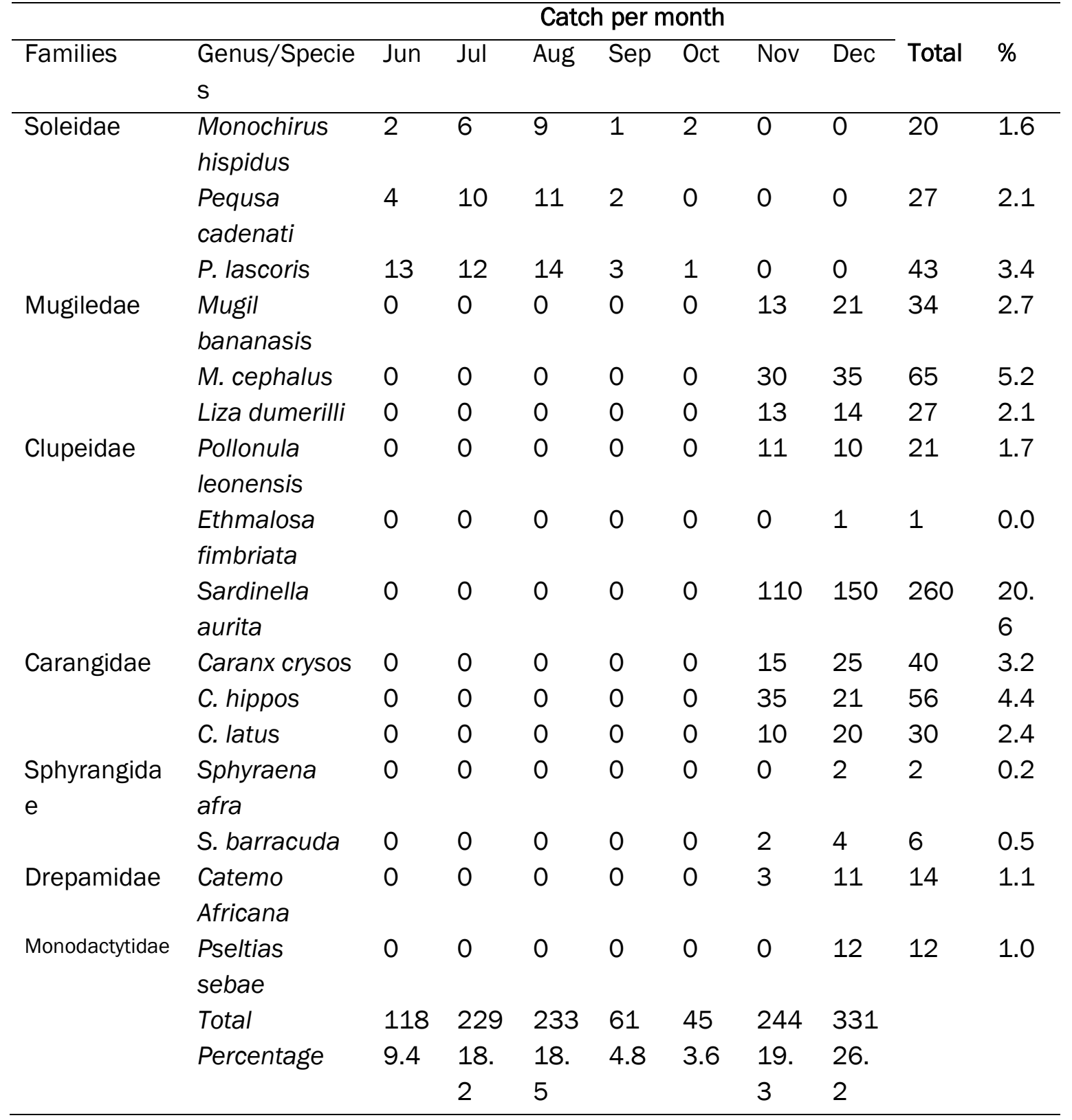


Table 3. Diversity indices of sampled fish species of Okerenkoko Estuarine

\begin{tabular}{llllll}
\hline Parameters & Z1 & Z2 & Z3 & Z4 & Z5 \\
\hline Individuals (N) & 231 & 231 & 264 & 152 & 383 \\
Simpson (1-D) & 0.68 & 0.81 & 0.89 & 0.85 & 0.88 \\
Shannon (H) & 2.08 & 2.98 & 3.81 & 1.97 & 2.54 \\
Evenness (E) & 0.31 & 0.63 & 0.85 & 0.66 & 0.73 \\
Margalef & 1.41 & 2.45 & 2.91 & 2.42 & 1.99
\end{tabular}

\section{DISCUSSION}

The responses of aquatic fauna to increasing pollution varies (Ewutanure and Olaifa, 2017). Changes in water quality caused by industrialization and technological development, are known to affect fish and other aquatic communities (Ohimain 2009). The overall number of species (1261) recorded in all the 5 stations during the study was higher compared with 34 and 91 species earlier reported by Ogaga et al., (2015b), Agada (1994) for Warri River. The number of species recorded was also higher than 58 species documented for flood plain rivers in Africa by Welcome (1979).

The increase in the number of fish species could be attributed to the constant flow of the Estuarine into the Atlantic Ocean as well as high amount of rainfall which to a great extent cause dilution of anthropogenic effluents along its course (Ewutanure and Olaifa, (2018a). Fish species that are unable to withstand the pollution effects of the Estuarine may die off or migrate to a more favourable environment, while those that can withstand the pollution effects survive (Ewutanure and Olaifa, 2018b).

The two similarity indices computed to compare fish species from the five stations showed that there was a remarkable dissimilarity among the stations in the study area (Ogaga et al. 2015b). The highly crude oil impacted (Station Z4) recorded the least species diversity. This may be linked with the uncontrolled discharge of toxic effluents by the petroleum industries which could be responsible for water quality impairment and the destruction of estuarine fisheries resources (Olaifa, 2006). Constants flow, higher amount of rainfall and tidal action might have been reasons for the relatively high diversity index recorded at Z3, Z2 and Z5, respectively. Similarly, Stations Z3 and Z2 with the highest diversity index could be associated with minimal anthropogenic activities in the study area.

\section{CONCLUSION}

Okerenkoko Estuarine is a major source of fish protein for the dwellers living along its course. This study revealed that oil and gas exploration, dredging, reclamation and effluents discharge may be responsible for the fluctuation in fish species diversity and number in Okerenkoko Estuarine. An overview of this work shows that the sources of pollution of the Okerenkoko Estuarine are linked with anthropogenic activities (petroleum industries). The accumulation of anthropogenic effluents may have contributed to the changes in its fish composition, abundance and diversity of Okerenkoko Estuarine. 
From the results of this study, it is therefore paramount to have the understanding of the social, economic and environmental consequences of the impact of pollutants on the Okerenkoko aquatic biota. It is expedient to control the amount and quality of effluent that enters the estuarine so as to avoid incessant pollution that could threaten its biodiversity.

\section{Acknowledgement}

I acknowledge the financial support received from Tertiary Education Trust Fund (TETFUND) through the Nigeria Maritime University, Okerenkoko, Warri South, Delta State, Nigeria. Many thanks for the encouragement and support received from the following people in my place of work: The Vice Chancellor, Professor Emmanuel Munakurogha Adigio; Dr J.T. Tuaweri; Dr P.A. Bariweni and Dr V.O. Eyo.

\section{REFERENCES}

Agada EGO. (1994) Heavy Metals Concentration in selected fish fauna of Warri River and its tributaries, Ph.D. Thesis, University of Benin, Benin City, Nigeria.

Aghoghovwia OA, Ohimain El, Akpovoka BB. (2015a). Heavy metals and physicochemical levels of effluents from industrial sewage treatment plant. Continental Journal of Biological Sciences, 4 (2): 1 - 8.

Ogaga, A.A., Olusegun, A.O. and Elijah, I.O. (2015b). Impacts of Industrialization on Fish Species composition and diversity in Warri River, Niger Delta, Nigeria. Journal of Geography, Environment and Earth Science International, 3(3): 1-10.

Aghoghovwia OA. (2008). Assessment of Industrial/Domestic Effluents/ Effects on Fish Species Diversity of Warri River Delta State, Nigeria. PhD thesis University of Ibadan Ibadan Nigeria.Pp. 72-116.

Baran, E. and Guerin, E. (2012). Fish bioecology in relation to sediment in the Mekong and Tropical Rivers. Report for the project A climate resilient Mekong: Maintaining the flows that Nourishes Life led by the Natural Heritage Institute, Cambodia 1 - 52.

Boulenger GA. (1909 - 1916). Catalogue of the Freshwater Fishes of Africa in British Museum (Natural History). British Museum of National History London. 5:1-4.

Egborge ABM. (1994). Water pollution in Nigeria. Biodiversity and chemistry of Warri River. Ben Miller Books Nigeria Limited ISBN 0- 999-768. 275-288.

Egborge ABM. (2001). Pollution of Warri River at Opete. Water Pollution in Nigeria. 2.

Egborge ABM. (2010). 4th Convocation Lecture Government, oil companies, the people and The Niger Delta Environment University of Benin, Benin city, Nigeria.

Ewutanure, S. J. And f. E. Olaif. (2017). Length -weight relationships and condition factor of Clarias gariepinus from Gbalegbe River, Delta State, Nigeria. Proceedings of the 32nd Annual National Conference of Fisheries Society of Nigeria held at Nnamdi Azikiwe University, Awka, Anambra State. 23rd -28th October, 2017. 329 - 332 Pp.

Ewutanure, S. J. and Olaifa, F. E. (2018a). Heavy metal concentrations in water and sediment of Gbalegbe River, Delta State, Nigeria. The 2nd SETAC Central/West Africa Regional Conference, Environmental sustainability and pollution control through science. Book of Abstract, $4 \mathrm{Pp}$. 
Ewutanure, S.J. \& Olaifa, F.E. (2021). Spatial and Temporal Fluctuations of Physico - Chemical Parameters, Nutrients and Primary Productivity of Gbalegbe River, Delta State, Nigeria Proceedings of the 28th iSTEAMS Intertertiary Multidisciplinary Conference. American International University West Africa, The GambiaSeries 28, Vol 3 October, 2021. Pp 1371 www.isteams.net/gambia2021. DOI - https://doi.org/ 10.22624/AIMS/iSTEAMS2021/V28N3P11.

Ewutanure, S.J. (2021). Field survey of Okerenkoko Estuarine, June 5th, 2021.

Ewutanure, S.J. and Olaifa, Flora. E. (2018b). Phytoplankton Species Composition, Distribution, Abundance and Diversity in Gbalegbe River, Delta State, Nigeria. Proceedings of $6^{\text {th }}$ NSCB Biodiversity Conference; Uniuyo, 164 - 170.

Flora E. Olaifa, Ibukun Omotola Akinrelere \& Jacob Somorhire Ewutanure (2019). Haematological, Biochemical and Histopathological Responses of African Catfish Clarias Gariepinus Juveniles to Sublethal Concentrations of Crude Oil in Water. Proceedings of the 18th iSTEAMS Cross-Border Conference, University of Ghana, Legon. 28th - 30th July, 2019. Pp 371-381 www.isteams.net - DOI Affix - https://doi.org/ 10.22624/AIMS/iSTEAMS-2019/V18N1P42

Holden M, Reed W. (1972). West Africa Freshwater Fishes Longman Group, London. 68 Pp.

Idodo - Umeh, I. 2003. Freshwater Fishes of Nigeria (Taxonomy, Ecological notes, diet and utilization). Idodo Umeh Publishers Limited, No. 52, Ewah Road, P.O.Box 3441, Benin City, Edo State, Nigeria. E-mail: idodoumeh@yahoo.com. 1 - 232.

Idodo-Umeh G. (1987). Studies on the Fish community of River Ase, Bendel State, with special emphasis on the food and feeding habits of Citharinidae, Schilbeidae and Mochokidae Ph.D. Thesis University of Benin.

Ita, E .0. 1993. Inland Fishery Resources of Nigeria. Central Insitute of Freshwater Aquaculture Occassional Paper, 20: 120-126.

Lloyd M, Ghehardi RJ. (1964). A table for calculating the equitability component of species diversity. Jn Anmal Ecol. 33:217-225.

Margalef R. (1961). Hidrografía y fitoplancton de un área marina de la costa meridional de Puerto Rico. Invest. Pesq. 18:33-96.

Nodu MB. Ohimain El. (2014). The effects of crude oil contaminated forage on breeding behavior and reproductive performance of female rabbits. International Journal of Plant, Animal and Environmental Sciences. 4(2):467-472.

Ogaga, A.A., Oyelese, O.A. and Ohimain, E.L. (2015). Heavy metal levels in water and sediment of Warri River, Niger Delta, Nigeria. International Journal of Geology, Agriculture and Environmental Sciences 3.1: 20- 24

Ogbeibu AE, Ezeunara PU. (2002). Ecological Impact of Brewery Effluent on the Ikpoba River. Using the fish communities as Biolndicators. J of Aquatic Sci. 17(1): 35-44.

Ohimain El, Agedah EC, Briyai FO. (2008a). Thioleaching of heavy metal contaminated sediments using Matin's medium. International Journal of Biotechnology and Biochemistry. 4(3):263-273. 15.

Ohimain El, Imoobe TOT, Bawo DDS. (2008b). Changes in water physico-chemistry following the dredging of an oil well access canal in the Niger Delta. World Journal of Agricultural Sciences. 4(6):752-758.

Ohimain El, Imoobe TOT, Benka-Coker M O. (2002) Impacts of dredging on zooplankton communities of Warri River, Niger Delta. African Journal of Environmental Pollution and Health. 1:37-45. 
Ohimain El, Olu DS, Abah SO. (2009). Bioleaching of Heavy Metals from Abandoned Mangrove Dredged Spoils in the Niger Delta; A Laboratory Study. World Applied Sciences Journal. 7(9):1105-1113. 10.

Ohimain El. (2008). Assessment of the impacts of dredging and drainage on the mangrove soils from selected rivers in The Niger Delta, Nigeria'. Intl. J. Nat. Appl. Sci. 4(3):299-304.

Okie - Anie Al. (1980). Food and feeding habits of the fishes of Ekurede-Urhobo Creek WarriB.Sc project supervised by Prof AB.M. Egborge University of Benin, Benin City Nigeria. 65-68.

Olaifa, F. E. 2003. Impact of oil spillage on the Fisheries resources of Cross River and Akwa Ibom states, Nigeria. A Ph.D. thesis in the department of Wildlife and Fisheries Management, Faculty of Agriculture\& Forestry, University of Ibadan, Nigeria. 12 - 156.

Olaifa, F. E., 2015. Food security: The perspective of Aquaculture and Fisheries. 2014/2015 Faculty lecture, Faculty of Agriculture and Forestry, University of Ibadan, Ibadan, Nigeria, $1-47$.

Reed W, Burchard J, Hopson Jenness J. (1967). Fish and Fisheries of Northern Nigeria. Ministry of Agriculture, Northern Nigeria, Zaria. 226 Pp.

Shannon CE, Weaver WW. (1963). The mathematical theory of communications. Urban, Illionis, Univ. of Illionois Press. 117. 